\title{
NOTE
}

\section{Cellulase activity in natural and temperature acclimated populations of Fundulus heteroclitus}

\author{
Timothy S. Moerland* \\ Department of Zoology and Migratory Fish Research Institute, University of Maine, Orono, Maine 04469, USA
}

\begin{abstract}
The cellulase activities of alimentary tissue and gut contents from field-collected and temperature-acclimated Fundulus heteroclitus were determined by a linked peroxidase and glucose oxidase end-point assay. Activity in tissue from natural populations of fish was significantly greater than that from laboratory-held animals. Tissue from fish collected at $6{ }^{\circ} \mathrm{C}$ possessed significantly higher activity than all other tissue samples, $43.11 \pm 15.03 \mu \mathrm{mol} \mathrm{mg} \mathrm{protein}{ }^{-1} \mathrm{~h}^{-1}$. Activity in tissue from animals collected at $31^{\circ} \mathrm{C}$ was $20.12 \pm 6.11$ $\mu \mathrm{mol} \mathrm{mg}$ protein ${ }^{-1} \mathrm{~h}^{-1}$. The activities of tissues from fish acclimated to 8,15 , and $25^{\circ} \mathrm{C}$ were $10.07 \pm 1.97,5.8 \pm 2.80$, and $6.87 \pm 2.54 \mu \mathrm{mol} \mathrm{mg}$ protein ${ }^{-1} \mathrm{~h}^{-1}$, respectively, and were not significantly different from each other. Gut contents from fish collected in the field at $6^{\circ} \mathrm{C}$ possessed cellulase

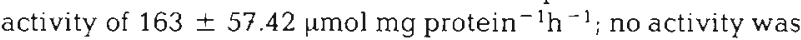
detected in gut content samples from fish collected at $31^{\circ} \mathrm{C}$ nor in any laboratory-held acclimation group. Cellulose may be a significant source of carbohydrate for natural populations of Fundulus heteroclitus.
\end{abstract}

The mummichog Fundulus heteroclitus occupies a key position in the trophic scheme of New England salt marshes. F. heteroclitus is a common fish of East Coast tidal marshes, and estimates of productivity per unit area for this species are among the highest reported for natural populations of fish (Valiela et al. 1977). $F$. heteroclitus may ingest large quantities of detritus (Darnell 1964, Nixon \& Oviatt 1973, Kneib \& Stiven 1978), although the available evidence suggests mummichogs derive little value from this resource. $F$. heteroclitus does not possess the anatomical features often associated with detritus utilization (i.e. increased gut length and absorptive surface area), and Prinslow et al. (1974) found that mummichogs held at $13^{\circ} \mathrm{C}$ could not utilize detritus for maintenance or growth. Kneib \& Stiven (1978) suggest detritus may be ingested

\footnotetext{
- Present address: Department of Radiology, Harvard Medical School, Brigham and Women's Hospital, 25 Shattuck Street, Boston, Massachusetts 02115, USA
}

by $F$. heteroclitus as an incidental consequence of taking prey that feeds on detritus.

The detritus pool in salt marsh communities is rich in decaying plant material (Darnell 1964, Gosselink \& Kirby 1974), and therefore represents an abundant source of cellulose. No vertebrate is known to produce cellulase, the enzyme that cleaves beta-1,4-glucan bonds between the glucose subunits of cellulose (Barnard 1973). However, cellulase activity, apparently of exogenous origin, has been detected in the digestive tracts of several fish species (Stickney \& Shumway 1974, Prejs \& Blaszczyk 1977, Lindsay \& Harris 1980). This finding implies that detritus may be a readily available source of carbohydrate for some fishes.

The present study has been prompted by a lack of information on cellulase activity in the digestive tract of Fundulus heteroclitus, and by reports that indicate metabolic demand for glucose, the end product of cellulose hydrolysis, changes with temperature in this species. Mummichogs exposed to near-freezing temperatures convert hepatic glycogen to glucose, resulting in a 4 - to 20 -fold increase in serum glucose levels (Umminger 1971). This cold-induced hyperglycemia is thought to be adaptive; elevated serum glucose may act as a cryoprotectant by stabilizing blood serum in a supercooled state (Umminger 1970, Parker 1972), or in a hypoosmotic environment the contribution of glucose to serum osmolality may compensate for a temperature-impaired capacity for ionic regulation (Umminger 1971). Perhaps in preparation for this hyperglycemic response to temperature, cold-acclimated $F$. heteroclitus establish substantial stores of hepatic glycogen (Moerland \& Sidell 1981). At warm temperatures (ca $25^{\circ} \mathrm{C}$ ), hepatocyte metabolism becomes increasingly reliant on glucose, whereas demand for lipid as an energy source falls significantly (Moerland \& Sidell 1981). This may reflect the lipid-intensive demands of 
gametogenesis, which also occurs at warm temperatures (Burger 1939, Matthews 1939). The specific objectives of this investigation were to assess the activity of cellulase in the digestive tract of $F$, heteroclitus in relation to temperature, and to compare the results from laboratory-held fish to those from field-collected animals.

Materials and methods. Specimens of Fundulus heteroclitus were collected from salt marshes in the Penobscot and Sheepscot Bays of Maine. Animals of both sexes, 3 to $7 \mathrm{~cm}$ in length and 2 to $8 \mathrm{~g}$ in weight, were held in aquaria at 12 to 15 ppt salinity (Instant Ocean, Aquarium Systems, Inc.) under a controlled photoperiod (LD 12:12). Fish were acclimated to temperatures of 8,15 , or $25^{\circ} \mathrm{C}\left( \pm 2 \mathrm{C}^{\circ}\right)$ for $5 \mathrm{wk}\left(8\right.$ and $\left.25^{\circ} \mathrm{C}\right)$ or $6 \mathrm{mo}\left(15^{\circ} \mathrm{C}\right)$, and were fed daily, ad libitum, with a ground mixture of trout pellets, squid, and brine shrimp, cast in gelatin (proximate analysis: protein $62 \%$, carbohydrate $31 \%$, lipid $7 \%$, glycogen $<1 \%$ ).

Field samples of Fundulus heteroclitus were from Harrington Marsh, Washington County, Maine. Collections were made during mid-afternoon ebb tides, on 19 July (ambient water temperature $=31^{\circ} \mathrm{C}$ ) and October 30, 1983 (water temperature $=6^{\circ} \mathrm{C}$ ). Fish were lured with pet food wrapped in several layers of fine-mesh nylon gauze, and were collected before any bait could be ingested. Alimentary canals (with contents) were excised and stored on ice for transport to the laboratory (ca 2 h). Samples were then transferred to liquid nitrogen and could be kept in this fashion for several months without loss of cellulase activity. Digestive tract tissue was separated from gut contents and carefully rinsed with several $\mathrm{ml}$ of ice-cold $0.5 \mathrm{M}$ $\mathrm{K}_{2} \mathrm{HPO}_{4}(\mathrm{pH} 7.5)$. Phosphate buffer was added to yield a $10 \%(\mathrm{w} / \mathrm{v})$ solution, which was homogenized at $0{ }^{\circ} \mathrm{C}$ with a Tissumizer blender for $2 \times 15 \mathrm{~s}$, then sonicated for $5 \mathrm{~s}$ with an Artek 'Sonic 300' ultrasound generator. Gut contents were similarily prepared, although it was necessary to pool the yield from 4 specimens to obtain an amount adequate for analysis.

Determinations of cellulase (EC 3.2.1.4) activity were performed by an end-point colorimetric assay, modified from Dahlquist (1968) and Day \& Workman (1982). The immediate product of cellulase activity, cellobiose, was converted to glucose via exogenous cellobiase. Glucose was then quantified by a linked glucose oxidase and peroxidase system coupled to odianisidine. One capsule of peroxidase/glucose oxidase (PGO) enzymes was dissolved in $24 \mathrm{ml} 0.5 \mathrm{M}$ potassium phosphate, $\mathrm{pH} 7.5$, to which was added $1 \mathrm{ml}$ stock $\left(0.8 \mathrm{mg} \mathrm{ml}^{-1}\right)$ o-dianisidine. Cellobiase activity in commercial preparations of PGO enzymes (Sigma) is adequate for this assay (see Day \& Workman 1982). Reactions were initiated by adding $0.25 \mathrm{ml}$ sample homogenate to $0.75 \mathrm{ml} 0.5 \mathrm{M}$ potassium phosphate,
$0.25 \%(w / v)$ carboxymethyl cellulose ( $\mathrm{pH} 7.5$ ), equilibrated to $30^{\circ} \mathrm{C}$. After $30 \mathrm{~min}$ incubation at $30^{\circ} \mathrm{C}$, reactions were quenched by placing the vessels in an icewater slurry. Hydrolysis of carboxymethyl cellulose was measured as $A_{460} 15 \mathrm{~min}$ after mixing $0.1 \mathrm{ml}$ incubation medium with $0.5 \mathrm{ml}$ PGO-dianisidine solution. Reaction rates were linear over time and were proportional to the amount of enzyme (homogenate or commercial cellulase preparations) added. Control experiments established that the concentration of carboxymethyl cellulose used was saturating. Results were calibrated against a glucose standard, and were corrected for background color development of controls in which homogenates were added after the reaction was quenched.

All reageants were from Sigma Chemical Co., St. Louis, and aqueous solutions were made with distilled, deionized water. Protein determinations were by the microbiuret procedure of Itzhaki \& Gill (1964), and statistical analyses were performed by Student-Neuman-Keuls's multiple range test (Steel \& Torrie 1960).

Results. Cellulase activity was detected in all preparations of digestive tract tissue. Tissue from field-collected animals consistently possessed greater levels of activity than did that from laboratory-held animals (Table 1). Activity in preparations from the $6{ }^{\circ} \mathrm{C}$ field

Table 1. Fundulus heteroclitus. Cellulase activity of digestive tract tissue and gut contents from temperature acclimated and field collected populations, given as $\mu \mathrm{mol}$ glucose liberated (mg protein $)^{-1} h^{-1}$. Means $\pm 95 \%$ confidence limits (N) Assays performed at $30^{\circ} \mathrm{C}$

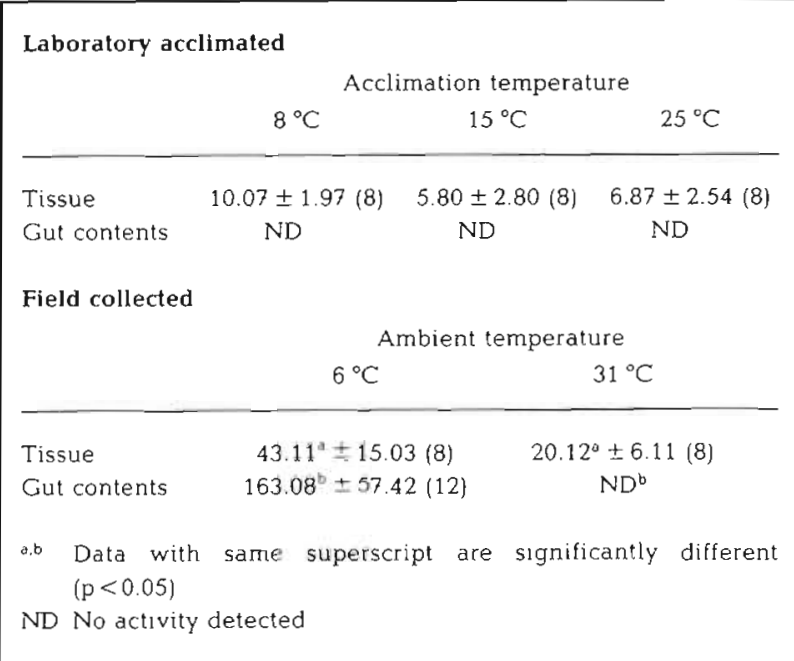

collection was significantly greater than any other tissue sample. No statistically significant differences were found between samples from animals acclimated to 8,15 , or $25^{\circ} \mathrm{C}$. The only sample of gut contents to exhibit detectable levels of cellulase activity was from the cold $\left(6^{\circ} \mathrm{C}\right)$ field collection. No activity was present 
in the controlled diet which was fed to laboratory animals during the acclimation regime.

Discussion. Two explanations have been proposed to account for the presence of cellulase, an enzyme not synthesized by vertebrates, in the digestive tracts of fish. The first suggests that the enzyme originates from cellulolytic organisms ingested with food items. In a study of 22 specimens ( 6 species), Prejs \& Blaszczyk (1977) found that cellulase activity was correlated with the amount of plant detritus in the digestive tract, and implied the enzyme was produced by microflora that had colonized plant material prior to ingestion. Lindsay \& Harris (1980) also reported that cellulase activity was related to food habits, however their examination of 138 specimens from among 42 species indicated the source was most likely a cellulolytic microflora within invertebrate prey items. Alternatively, Stickney \& Shumway (1974) suggest a stable, cellulase-producing microflora may exist within the alimentary tract of fishes. These hypotheses are not mutually exclusive, and cellulase activity in Fundulus heteroclitus may have multiple origins.

At least some cellulase in mummichogs may originate from a relatively stable intestinal microflora. Cellulase was detected in all tissue samples tested, including those from a population held in aquaria for approximately 6 mo. This group $\left(15^{\circ} \mathrm{C}\right.$ acclimated) was fed a controlled diet that had no intrinsic cellulase activity, yet levels of activity in these fish were not significantly different from those in laboratory populations that were held only $5 \mathrm{wk}$ prior to experimentation. Therefore, the proximate source of at least some cellulase activity in Fundulus heteroclitus is persistent over time, is not related to an animal's immediate dietary history, and is intimately associated with the lining of the alimentary canal. These features are consistent with the presence of a stable, cellulase-producing intestinal microflora.

Cellulase might also be derived from ingested items. The only preparations of gut contents with detectable levels of activity were from fish of the autumn $\left(6{ }^{\circ} \mathrm{C}\right)$ field collection. The detritus pool is enriched at this time with frost-killed Spartina undergoing the first stages of microbial attack (see Jeffries 1972, Gosselink \& Kirby 1974). Autumn is also when mummichogs would normally be establishing glycogen stores necessary for the previously mentioned hyperglycemic response to freezing temperatures. Fundulus heteroclitus may obtain cellulase during this time of peak physiological demand for glucose both from synthesis by resident microflora and from cellulolytic microorganisms associated with ingested material. The general observation that cellulase activity was higher in field-collected mummichogs than in acclimated specimens may reflect the fact that laboratory-held indi- viduals did not receive the enzyme from ingested material.

Prinslow et al. (1974) found that Fundulus heteroclitus fed detritus plus a commercial fish food did not grow more rapidly than those fed only fish food, and that mummichogs fed only detritus could not maintain body mass. However, the experimental animals of Prinslow et al. (1974) were held in aquaria at approximately $13^{\circ} \mathrm{C}$ and were fed detritus that was collected by skimming tidal creeks. The present data implicate holding conditions, dietary input, and temperature as factors related to variations in cellulase activity. Detritus (via cellulase) may be a significant source of glucose for feral populations under a naturally occurring combination of temperature and dietary conditions that were absent from the experiments of Prinslow et al. (1974).

The intestinal morphology and physiology of Fundulus heteroclitus may be uniquely suited to capitalize on the digestive capabilities of exogenous microorganisms, whether resident or ingested with food. The 'stomachless' fishes, of which $F$. heteroclitus is an example, do not secrete gastric pepsins or $\mathrm{HCl}_{\text {; }}$ instead, digestive fluids are neutral or slightly alkaline (Babkin \& Bowie 1928, Barnard 1973). Inasmuch as acidic digestive processes kill living cells (Barnard 1973), microorganisms might be conserved in the alimentary environment of $F$. heteroclitus.

A comparison can be drawn at approximately $30^{\circ} \mathrm{C}$ between the respiratory rate of Fundulus heteroclitus and the caloric potential of cellulolytically-derived glucose. From the weight and temperature regression analysis of Targett (1978), the routine respiratory rate of a representative $5 \mathrm{~g}, 29^{\circ} \mathrm{C}$ acclimated mummichog at $29^{\circ} \mathrm{C}$ is approximately $2.8 \mathrm{ml} \mathrm{O}_{2} \mathrm{~h}^{-1}$, or $13.5 \mathrm{cal} \mathrm{h}^{-1}$. Specimens of the $31^{\circ} \mathrm{C}$ field collection were of similar mass and possessed, on average, $60 \mathrm{mg}$ (wet weight) digestive tract tissue with an average total protein content of $4.6 \mathrm{mg}$. Therefore, specimens of the $31^{\circ} \mathrm{C}$ field collection possessed the capacity to liberate approximately $92 \mu \mathrm{mol}$ glucose $\mathrm{h}^{-1}$ from cellulose, or $62 \mathrm{cal} \mathrm{h}^{-1}$. The conversion values applied are $673 \mathrm{kcal}$ $\mathrm{mol}^{-1}$ glucose oxidized and $4.8 \mathrm{cal} \mathrm{ml} \mathrm{O}_{2}^{-1}$ (Hill 1976), and this calculation assumes that the activity of cellulase is not limited by substrate availibility. Although rates of cellulose degradation in situ may be less than this calculated maximum, glucose produced by cellulolytic activity could represent a significant fraction of the total respiratory demands of $F$. heteroclitus at warm temperatures. Similar calculations for cold temperatures are not possible because cellulase activity was assayed only at $30^{\circ} \mathrm{C}$; however, the conclusion that cellulolytic activity could meet a substantial part of the physiological demand for glucose should be equally applicable to mummichogs at lower temperatures. 
Acknowledgements. This research was supported in part by NSF PCM 81-04112 to Bruce D. Sidell. Thanks to Drs Sidell, J. $M$. Shick, and T Targett for critical evaluation of the manuscript.

\section{LITERATURE CITED}

Babkin, B. P., Bowie, D. J. (1928). The digestive system and its function in Fundulus heteroclitus. Biol. Bull mar biol. Lab., Woods Hole 54: 254-277

Barnard, E. A. (1973). Comparative biochemistry and physiology of digestion. In: Prosser, C. L. (ed.) Comparative animal physiology, 3rd edn. W. B. Saunders, Philadelphia, p. $133-164$

Burger, J. W (1939). Some experiments on the relation of the external environment to the spermatogenetic cycle of Fundulus heteroclitus. Biol. Bull. mar biol. Lab. Woods Hole 77: $96-103$

Dahlquist, A. (1968). Assay of intestinal disaccharidases Analyt. Biochem. 22: 99-107

Darnell, R. M. (1964). Organic detritus in relation to secondary production in aquatic communities. Verh. int. Verein. Limnol. 15: 462-470

Day, D. F., Workman, W. E. (1982). A kinetic assay for cellulases. Analyt. Biochem. 126: 205-207

Gosselink, J. G., Kirby, C. J. (1974). Decomposition of salt marsh grass, Spartina alterniflora Loisel. Limnol. Oceanogr. 19: 825-832

Hill, R. W. (1976). Comparative physiology of animals: an environmental approach. Harper \& Row, New York.

Itzhaki, R. F., Gill, D. M. (1964). A microburet method for estimating proteins. Analyt. Biochem. 9: 401-410

Jeffries, H. P. (1972). Fatty acid ecology of a tidal marsh. Limnol. Oceanogr. 17: 433-440

Kneib, R. T., Stiven, A. E. (1978). Growth, reproduction and feeding of Fundulus heteroclitus (L.) on a North Carolina salt marsh. J. exp. mar. Biol. Ecol. 46: 89-98

Lindsay, G. J. H., Harris, J. E. (1980). Carboxymethylcellulase activity in the digestive tracts of fish. J. Fish Biol. 16: 219-233
Matthews, S. A. (1939). The effects of light and temperature on the male sexual cycle in Fundulus heteroclitus. Biol. Bull. mar. biol. Lab., Woods Hole 77 : 92-95

Moerland, T. S., Sidell, B. D. (1981). Characterization of metabolic carbon flow in hepatocytes isolated from thermally acclimated killifish Fundulus heteroclitus. Physiol. Zool. 54: 379-389

Nixon, S. W., Oviatt, C. A. (1973). Ecology of a New England salt marsh. Ecol. Monogr. 43: 463-498

Parker, J. (1972). Spatial arrangement of some cryoprotective compounds in ice lattices. Cryobiology 9: 247-250

Prejs, A., Blaszczyk, M. (1977). Relationships between food and cellulase activity in freshwater fishes. J. Fish Biol. 11: $447-452$

Prinslow, T. B., Valiela, I., Teal, J. M. (1974). The effect of detritus and ration size on the growth of Fundulus heteroclitus (L.). J. exp. mar. Biol. Ecol. 16: 1-10

Steel, R. G. D., Torrie, J. H. (1960). Principles and procedures of statistics. McGraw-Hill, New York

Stickney, R. R., Shumway, S. E. (1974). Occurrence of cellulase activity in the stomachs of fishes. J. Fish Biol. 6: $779-790$

Targett, T. E. (1978). Respiratory metabolism of temperature acclimated Fundulus heteroclitus. (L.): zones of compensation and dependence. J. exp. mar. Biol. Ecol. 32: $197-206$

Umminger, B. L. (1970. Physiological studies on supercooled killifish Fundulus heterclitus. III. Carbohydrate metabolism and survival at subzero temperatures. J. exp. Zool. 173: $159-174$

Umminger, B. L. (1971). Osmoregulatory role of serum glucose in freshwater-adapted killifish (Fundulus heteroclitus) at temperatures near freezing. Comp. Biochem. Physiol. 38A: 141-145

Valiela, J., Wright, J. E., Teal, J. M., Volkmann, S. B. (1977). Growth, production and energy transformations in the salt-marsh killifish Fundulus heteroclitus. Mar. Biol. 40: 135--144

Accepted for printing on August 2, 1985 